\title{
Determinants of Market Orientation of Smallholder Wheat Farmers in Northern Ethiopia
}

\author{
Dubale Abate ${ }^{1,}$, Fikadu Mitiku ${ }^{2}$, Rijalu Negash ${ }^{2}$ \\ ${ }^{1}$ Department of Agribusiness and Value Chain Management, Wolkite University, Wolkite, Ethiopia \\ ${ }^{2}$ Department of Agricultural Economics and Agribusiness Management, Jimma University, Jimma, Ethiopia
}

Email address:

dubaleawoke12@gmail.com (D. Abate)

${ }^{*}$ Corresponding author

\section{To cite this article:}

Dubale Abate, Fikadu Mitiku, Rijalu Negash. Determinants of Market Orientation of Smallholder Wheat Farmers in Northern Ethiopia. American Journal of Science, Engineering and Technology. Vol. 5, No. 3, 2020, pp. 110-117. doi: 10.11648/j.ajset.20200503.11

Received: August 28, 2020; Accepted: September 15, 2020; Published: September 25, 2020

\begin{abstract}
In Ethiopia, wheat is a market-oriented commodity although farmers are still producing this crop for consumption than for market, not based on the market information. The main objective of the study was to identify the determinants of market orientation of smallholder wheat farmers. The data were collected from 190 randomly selected sample households using structured questionnaire. Descriptive statistics and Tobit model were used for analyzing smallholder wheat farmers' market orientation and its determinants. Descriptive statistics revealed that the average market orientation index of the sample wheat farmers was $10.69 \%$, very low. The results of Tobit model revealed that land size, market access, wheat market experience, extension contact and equine owned were positively and significantly affecting market orientation of wheat whereas family size, total input cost and off/none farm income were significantly and negatively influencing market orientation. Therefore, designing an integrated policy and strategy on improving market access, provision of extensions mainly on market area and productivity of land for wheat while reducing the input cost would be suggested to improve market orientation of smallholder wheat farmers.
\end{abstract}

Keywords: Market Orientation, Smallholder Farmers, Wheat, Tobit Model, Sayint Adjibar, Ethiopia

\section{Introduction}

In developing countries including Ethiopia, cereals are the main source of food intake $(60 \%)$, which are predominantly produced by small landholders [10]. It covers the highest percentage in terms of area coverage and volume of production by 80.71 and $87.48 \%$, respectively, than other crops with in the country, Ethiopia. Its production and marketing is also playing a great role to boost economic growth and development and for improving the livelihood of the smallholder farmers in the country [8].

Wheat is among the most important and largely produced cereal crops, which covers 1.6 million hectares of land, 3.9 million tons of production and 4.7 million farmers engagement in Ethiopia [2]. The highlands of the central, south-eastern and northwest parts of the country are the main wheat growing areas of Ethiopia; mainly produced in Oromia $(57.4 \%)$ and Amhara regions $(27 \%$ of the national production) [5]. It is used as a staple and an industrial crop because of its use as a raw material for many food industries like in flour, pasta, macaroni and other related industries in the country [11]. However, it is currently categorizing as an industrial crop rather than staple food crop due to its uses and high demand in food industries [7]. Therefore, wheat is an important cereal crop used mainly for the preparation of many food items in different food industries besides its stapled food.

Wheat is also a market oriented commodity, which is an income generating venture for many smallholder farmers in Ethiopia in general and the study area (Sayint Adjibar) in particular. This means that, besides its production for consumption $(60 \%)$, smallholder farmers are producing wheat for market (20\%) [1]. However, they are mostly producing it without market information provided that they are not market oriented and supply it in the market simply when cash is required/ needed. Besides this, the smallholder farmers are not participating enough in the market because of 
low production [3]. As a result, they get minimum benefits and their living standard in not improved, not out of poverty. Therefore, instigating the smallholder farmers to be a market participant and oriented so as to improve their income and living standard by producing wheat based on market signal (market orientation) is crucial.

Even though smallholder farmers' market orientation of wheat plays a great role for boosting the country's economic growth and development and living standard of smallholder farmers by transforming the traditional production to market oriented production system, the farmers are still producing it without market signal due to different factors. There is no (little) researches conducted to identify those factors affecting smallholder farmers' market orientation of wheat production. But there are researches on wheat production, marketing (participation) and commercialization. For example, a research on the analysis of wheat commercialization in Ethiopia was conducted [11]; but these authors were not looking at market orientation with its intensity specifically. Additionally, a research entitled "Commercialization of smallholders: Does market orientation translate into market participation?" was conducted [9]. These authors tried to analyze the market orientation index of crop outputs; but not on wheat market orientation specifically. Besides this, the governments of Ethiopia are promoting the smallholders to diversify their production and production of market oriented products for transforming traditional production system to modern/market oriented production in order to accelerate economic growth, expand employment opportunities, and reduce rural poverty [14]. But, it is not fruitful for transformation, and farmers are not yet out of subsistence oriented production, not market oriented. Additionally, their researches on smallholder commercialization (market orientation) of agricultural crops were not addressing/incorporating all areas of the country including the study district. Likewise, no research on smallholder farmers' market orientation of wheat production, especially the factors affecting it, is not conducted in the study district. Therefore, this research was designed to identify the factors affecting the market orientation of smallholder wheat farmers' in Sayint Adjibar, Northern Ethiopia.

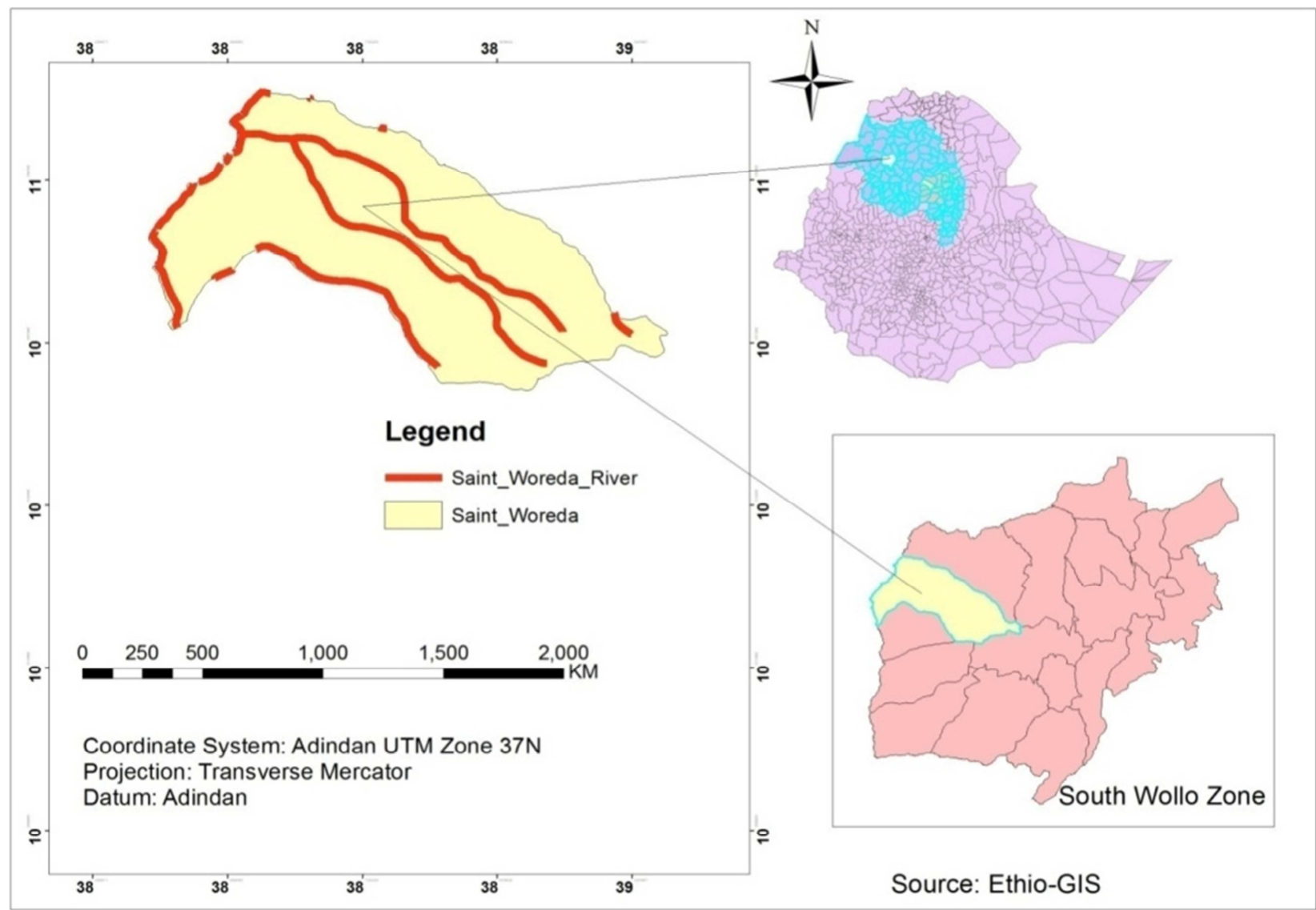

Figure 1. Geographic map of the study district.

\section{Research Methods}

\subsection{Description of Study Area}

The study was conducted in Sayint Adjibar (Amhara
Sayint) districts of Amhara region in Ethiopia. The district is located about 587 kilometers north of Addis Ababa, the capital city of Ethiopia, and 187 kilometer south west of Dessie, the zonal city of South Wollo. The district is bordered on the south by Debresina and Mehal Sayint, on the west by the Blue Nile that separates it from the East Gojjam Zone, on 
the northwest by the Beshilo River that separates it from the South Gondar Zone, on the north by Maqidala, on the east by Tenta and on the southeast by Legambo. The major town in Sayint is Sayint Adjibar. The altitude of the district ranges from 500-3700 meter above sea level. The total population of the district is 144,972 (71,979 men and 72,993 women) with the population density of 100.86 per square kilometer [4]. A total of 34,999 households were counted in this Woreda, resulting in an average of 4.14 persons per household, and 33,604 housing units.

The main source of economy in Sayint Woreda is crop production supplemented by livestock rearing [6]. The dominant types of crops cultivated in the district are wheat (Triticum vulgar), barley (Hordeum vulgar), field pea (Pisum sativa), bean (Vicia faba), potato (Solanumtu berosum), Teff (Eragrostis teff), Onion (Alliu bcepa) and pulses. All crops are grown for both consumption and sale but the pulses are particularly aimed at the market, whereas the dominant livestock in the area are sheep, cattle, horses, bees and poultry.

\subsection{Data Types and Sources}

Both qualitative and quantitative data were collected from both primary and secondary sources. The qualitative data collected were the nature and characteristics of the household. The quantitative data that were collected included quantity of wheat, price and cost of the wheat, size of land in hectare, income, number of livestock, amount of fertilizer. The sampled respondents' were sources of primary data whereas the district's annual reports, statistical agency, published and unpublished documents were secondary data sources.

\subsection{Sampling Technique and Sample Size Determination}

Three stage sampling procedure was used to take the sample respondents. In the first stage, the potential wheat growing kebeles were identified from the district with the help of agricultural office and developmental agents. In view of that, eight potential wheat producing kebeles were identified from 35 kebeles in the district. In the second stage, four wheat grower kebeles namely, Shengo-defer, Ashinga, Fers-bar and Ambaferit were randomly selected from eight wheat producing kebeles. Finally, the sample respondents were selected randomly and proportionally from the four kebeles.

Yamane formula (1967) was to determine the sample size of the respondents at $95 \%$ level of confidence with precision level of $7 \%$ to estimate the true population. Consequently, 190 sample respondents were randomly selected from four kebeles. Using proportional methods, 38, 42, 54 and 56 sample respondents were randomly selected from Ambaferit, Fers-bar, Ashinga and Shengo-defer Kebeles respectively. Mathematically, the sample size could be determined as follows:

$$
n=\frac{N}{1+N\left(e^{2}\right)}=\frac{2580}{1+2580\left(0.07^{2}\right)}=190 \text { Sample households }
$$

Where, $\mathrm{N}=$ total population $=2580, \mathrm{n}=$ sample size and $\mathrm{e}=$ error term $=7 \%$

The following table shows the selected kebeles with their total households, proportion and sample size.

Table 1. The selected kebeles, total population, proportion and number of respondents.

\begin{tabular}{lllll}
\hline No & Name of Kebeles & Total Population & Proportion & Sampled respondent \\
\hline 1 & Ambaferit & 513 & 0.199 & 38 \\
2 & Ashinga & 737 & 0.286 & 54 \\
3 & Fers-bar & 572 & 0.222 & 42 \\
4 & Shengo-defer & 758 & 0.294 & 56 \\
& Total population & 2580 & 1 & 190 \\
\hline
\end{tabular}

Source: Woreda's statistical report, 2017; own computation, 2018.

\subsection{Method of Data Collection}

The data were collected from the sample household using the structured questionnaire and check list. In the first stage, the structured questionnaire was prepared and pretested on some respondents for clarity, completeness and relevance to collect the primary data. Then, the questionnaire was amended according to the feedback for the pretest, and then using the modified questionnaire the sampled households were interviewed to get the primary data. Besides this, the primary data were also collected informally by asking the key informants, who are expected to have knowledge about it using checklist. In addition to these, observation of the areas in the study district was used as a method to collect the primary data. The secondary data were collected through reviewing different published and unpublished documents, district's agricultural product reports in the district.

\subsection{Methods of Data Analysis}

The data collected for achieving all objectives in the study area were analyzed using appropriate statistical software, both SPSS (version 20) and STATA (version 13) software. Both descriptive and econometric analyses were used for analyzing the data.

Descriptive statistics such as mean, minimum, maximum value and standard deviation were used to analyze the demographic characteristics of the sampled households and market orientation index. Market orientation index was used to measure the intensity of market orientation of wheat production which can be calculated as the proportion of the amount of land allocated for wheat to the total crop land operated by a household. 
Mathematically, market orientation index was calculated as

$$
M O R I=\frac{\sum_{w=1}^{w}\left(\alpha_{k} L_{k}\right)}{L_{i}^{T}}, L_{i}^{T}>0 \text { and } 0<M O R I \leq 1
$$

Where, MORI is market orientation index of household $i$; $L_{k}$ is amount of land allocated to wheat; and $L_{i}{ }^{T}$ is the total crop land operated by household $i ; \alpha_{k}$ is Marketability index of each crop, which can be calculated as:

$$
\alpha_{k}=\frac{\sum_{i=1}^{N} S_{W i}}{\sum_{i=1}^{N} Q_{W i}} ; Q_{W i} \geq S_{W i} \text { and } 0 \leq Q_{W i} \leq 1 .
$$

Where, Swi is the proportion of wheat sold and Qwi is the total amount wheat produced.

To analyze the determinants of wheat market orientation indices, Tobit model were employed since the factors affecting the orientation decision and its intensity were the same. Besides this, not all farmers were market oriented (there were censored data) so that Tobit model was preferred to analyze it. Some authors used Tobit regression analysis for estimating the market orientation indices. For instance, Tefera employed a Tobit regression analysis to estimate the market orientation indices of pulse [15]. Similarly, this study used this model to analyze the wheat market orientation.

$$
Y_{i}=\beta_{0}+\beta_{i} X_{i}+\varepsilon_{i} \text { and } Y=\left\{\begin{array}{l}
Y_{i} \text { if } \beta_{0}+\beta_{i} X_{i}+\varepsilon_{i}>0 \\
0 \text { if } \beta_{0}+\beta_{i} X_{i}+\varepsilon_{i} \leq 0
\end{array}\right.
$$

Where, $\mathrm{Y}$ is market orientation indices; $\mathrm{Y}_{\mathrm{i}}$ is latent variable; $X_{\mathrm{i}}$ is the independent variables; $\beta_{0}$ and $\beta_{\mathrm{i}}$ are the parameters to be estimated; $\varepsilon_{\mathrm{i}}$ is error term

For this study, market orientation, $\mathrm{Y}_{\mathrm{i}}>0$, can be formulated as follows:

Market orientation $\left(\mathrm{Y}_{\mathrm{i}}\right)=\beta_{0}$ Age $+\beta_{1}$ Sex $+\beta_{2}$ Family size + $\beta_{3}$ Ex. Mkt $+\beta_{4}$ Education $+\beta_{5}$ Access to market $+\beta_{6}$ Livestock + $\beta_{7}$ Labour $+\beta_{8}$ Land $+\beta_{9}$ Variety $+\beta_{10}$ Credit $+\beta_{11}$ Extension + $\beta_{12}$ Distance $+\beta_{13}$ Pcost $+\beta_{14}$ Oxen $+\beta_{15}$ Fertilizer $+\varepsilon_{\mathrm{i}}$

The estimation of Tobit model is determined through using maximum likelihood estimation, formulated as:

$\ln \mathrm{L}=\ln \left(\bigsqcup_{y>o} f(y i) \bigsqcup_{y=0} f(0)=\sum_{y>0} f(y i)+\sum_{y=0} f(0)\right.$

The coefficients of Tobit model are interpreted after marginal effects are calculated. These marginal effects are categorized in to three. These are the conditional expectation of dependent variables on latent variable $\left(\mathrm{y}^{*}\right)$; the conditional expectation of the observed dependent variable (y); and the conditional expectations of the uncensored observed dependent variable $(y \mid y>0)$. These marginal effects could be given as $\frac{\partial \mathrm{E}(y * / x)}{\partial x}=\beta$,

\begin{tabular}{|c|c|c|}
\hline Variables & Type of data & Expected sign \\
\hline Age of household (Age) & Continuous & + \\
\hline Sex of household (Sex) & Dummy & + \\
\hline Family size (FamSiz) & Continuous & - \\
\hline Experience in wheat market (ExMkt) & Continuous & + \\
\hline Educational status (EdHH) & Continuous & + \\
\hline Access to market (mkt) & Dummy & + \\
\hline Livestock (excluding oxen \& equines) (Livstk) & Continuous & - \\
\hline Quantity of wheat produced (Qnty) & Continuous & + \\
\hline Land Size of wheat (Land) & Continuous & + \\
\hline Access to improved variety (Variety) & Dummy & + \\
\hline Credit use (credit) & Dummy & + \\
\hline Frequency of extension contacts (Extension) & Continuous & + \\
\hline Distance to the nearest market (DMKT) & Continuous & - \\
\hline Distance to all weather roads (DallWR) & Continuous & - \\
\hline Production cost (Pcost) & Continuous & - \\
\hline Oxen owned (oxen) & Continuous & + \\
\hline Equines owned (equines) & Continuous & + \\
\hline Amount of Fertilizer & Continuous & + \\
\hline
\end{tabular}
$\frac{\partial \mathrm{E}(y / x)}{\partial x}=\beta \phi\left(\frac{x \beta}{\sigma}\right)$ and $\frac{\partial \operatorname{Pr}\left(y>\frac{0}{x}\right)}{\partial x}=\frac{\phi\left(\frac{x \beta}{\sigma}\right) \beta}{\sigma}$ respectively.

Table 2. Summary of independent variables used in the model with expected sign on wheat market orientation.

\section{Result and Discussion}

\subsection{Descriptive Statistics}

Descriptive statistics of variables used in Tobit regression analysis are summarized in Table 3 . The survey result showed that $83.16 \%$ of the total sampled respondents were male-headed household while the remaining $16.84 \%$ were female-headed house hold. The age of the sampled household was ranging from 18 to 85 years with an average of 48 years. The average family size of the sampled respondent in adult equivalent was 4.41. The average number of schooling completed was 3.56 years (almost $4^{\text {th }}$ grade). The mean of land size owned by sampled respondents was 1.90 hectare. However, the average size of land allocated for wheat by 
sampled respondents was 0.40 hectare. The average number of equine was 0.25 TLU. Averagely, the amount of wheat produced by sampled household was 6.44 quintals per 0.4 ha. On average, about $51.58 \%$ of the respondents got market access. The average-walking hour that took to arrive to the nearest market and all weather roads were 2.03 and 1.17 hours respectively.

Table 3. Descriptive statistics for variables used in econometric model.

\begin{tabular}{|c|c|c|c|c|c|}
\hline Variable & $\mathbf{N}$ & Mean & Std. Dev. & Min & $\operatorname{Max}$ \\
\hline Age (year) & 190 & 48 & 15.32678 & 18 & 85 \\
\hline Sex (Male/female) & 190 & .8315789 & .3752285 & 0 & 1 \\
\hline Family size (AE) & 190 & 4.405263 & 1.819638 & 1 & 10 \\
\hline Education (year) & 190 & 3.563158 & 4.058267 & 0 & 17 \\
\hline Land size of wheat (ha) & 190 & .4026868 & .2948008 & 0 & 2 \\
\hline Amount of fertilizer (quintal) & 190 & 1.066263 & .8903392 & 0 & 4 \\
\hline Improved Variety (yes/no) & 190 & .5578947 & .497949 & 0 & 1 \\
\hline Total Input Cost (birr) & 190 & 1775.438 & 1478.519 & 0 & 6530 \\
\hline Market access (yes/no) & 190 & .5157895 & .501071 & 0 & 1 \\
\hline Wheat market experience (year) & 190 & 9.121053 & 10.54249 & 0 & 40 \\
\hline Distance to nearest market (hour) & 190 & 1.233158 & 1.028271 & 0 & 6 \\
\hline Distance to all weather road (hour) & 190 & .7727895 & .7212512 & 0 & 3 \\
\hline Extension contact (number) & 190 & 1.510526 & 1.428136 & 0 & 6 \\
\hline Credit (yes/no) & 190 & .4842105 & .501071 & 0 & 1 \\
\hline Quantity of wheat produced (quintal) & 190 & 6.440789 & 5.218327 & 0 & 30 \\
\hline Equine (TLU) & 190 & .2507895 & .4928182 & 0 & 3.35 \\
\hline Oxen (TLU) & 190 & 1.026316 & .9673736 & 0 & 4 \\
\hline TLU Excluding Oxen \& equine (TLU) & 190 & 1.469347 & 1.521717 & 0 & 7.441 \\
\hline
\end{tabular}

\subsection{Market Orientation Index of Smallholder Wheat Producers}

The level of market orientation is measured by market orientation index, which can be calculated by dividing the product of marketability index and land allocated for the specific crop, wheat in this case, by total land allocated for all crops by sampled household. The survey result revealed that the average market orientation index of wheat producers was $10.69 \%$ with the minimum and maximum value of 0 and $100 \%$ respectively. This showed that the farmers are under the lower level of market orientation by wheat. This was due to the fact that most of the smallholder wheat farmers were producing their products for their consumption needs rather than for the market. Besides, the wheat producers in the study area did not sufficiently adopt the agricultural technology and apply the best agronomic practices. Due to these reasons they produce small amount of wheat, which is not enough to supply in the market as a result they become non oriented in wheat market.

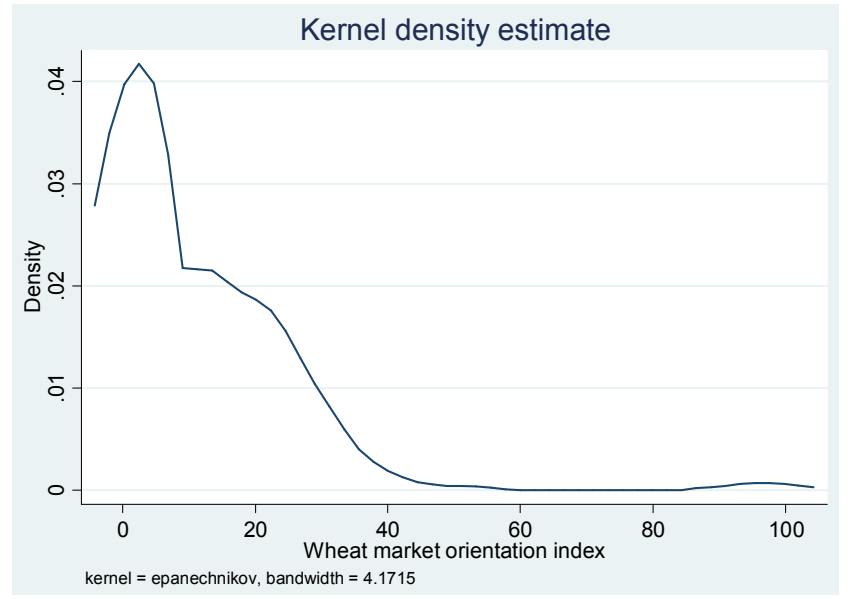

Figure 2. Kernal density estimation of market orientation index of wheat production in study area.

Table 4. Wheat produced, sold, and market orientation index.

\begin{tabular}{|c|c|c|c|c|c|}
\hline Variable & $\mathbf{N}$ & Mean & SD & Minimum & Maximum \\
\hline Wheat produced & 190 & 6.44 & 5.22 & 0 & 30 \\
\hline Wheat sold & 190 & 1.38 & 2.38 & 0 & 14 \\
\hline Market orientation Index & 190 & 0.1069 & 14.1 & 0 & 100 \\
\hline
\end{tabular}

\subsection{Econometric Results: Factors Affecting Market Orientation of Smallholder Wheat Producers}

After the econometric problems were detected/checked using appropriate test statistics, Tobit regression model was employed to identify the determinants of smallholder wheat farmer's market orientation. The likelihood function of market orientation index was highly significant at $1 \%$ (LR chi2 $(20)=116.13$ with the probability of Prob $>$ chi $2=0.0000)$ indicating a strong explanatory power of independent variables to explain market orientation intensity of wheat production (goodness of fit of the model). Besides this, Akaike Information Criteria was used to specify the model 
and the result showed that Tobit model was preferred to other model.

The model result showed that the variables like family size, land size, market access, wheat market experience, extension contact, off/none farm income, equine owned and total input cost were significantly affecting the market orientation.

Family size: This variable is a continuous variable measured in Adult equivalent ratio, had significant and negative effects on market orientation at 5\% significant level. The marginal effect result indicated that as the family size increased by one adult equivalent, the probability of being market oriented would be decreased by $14.53 \%$ where as it decreased the intensity of market orientation of wheat by 3.34 and 2.36 for the whole population of the study and for those who have already oriented in wheat production respectively, other things remain constant. This was because as the number of family member increased, the wheat produced would be used for consumption rather than supplying it in the market so that the wheat produced based on market signal is low. This is in line with the finding of Weldeyohanis, who showed that larger family size decreases market orientation of malt barely producers due to its effect on increasing household domestic consumption requirements [16].

Land size of wheat: This variable is positively associated with market orientation of wheat farmers provided that a one hectare increase in land size of wheat could increase the probability of being market oriented by $58.36 \%$ while its intensity of market orientation increased by 13.41 and 9.47 for whole sample and for market oriented wheat producers respectively at $1 \%$ significance level, other things remain constant. This means that if larger size of land is allocated for wheat production, the more likely to be a market oriented wheat farmers due to the highest wheat production that led farmers to supply more and produce based on market signals. This is in line with Onubuogu and Onyeneke, who found that if the farm size allocated for root and tuber is larger, the probability of being market oriented in root and tuber crops production was increased [12]. On the other hand, this finding is in contrast with the finding of Tefera, who found a negative relationship of land size and market orientation of Haricot bean [15].

Total input cost: It is negatively related with the market orientation and its intensity, provided that if the total input cost of wheat increased by one birr, the probability of being market oriented was decreased by $0.0057 \%$ while its intensity was decreased by 0.0013 and 0.00092 for whole sample and for those who are market oriented respectively, keeping other variables constant. This was due to the fact that the increased costs of production discourage the farmers from using those inputs so that they became unable to produce higher quantity of wheat that in turn decreased their supply. As a result, they did not have market information so that they become non-market oriented. This finding is consistent with the finding of Weldeyohanis, who found this variable as a significant with negative results in affecting market orientation of malt barely producers [16].

Market access: It had positive and significant effects on market orientation of smallholder wheat producers at $1 \%$ significant level so that as compared to non-market accessed wheat farmers, the accessed farmers were more likely to be market oriented. Keeping other variables constant, the change in the probability of orientation, intensity of dependent variable among the whole population and intensity among the market oriented only would increase by $0.28 \%$, 6.56 and 4.68 respectively if the farmer was accessed to wheat market than none accessed. This confirmed the finding of Siziba et al., who found that access of price information had positively significant effects on market orientation of cereals [13].

Wheat market experience: This variable was positive and significant at $10 \%$ significant level, thus positively affecting the wheat farmer's market orientation. This means that as the wheat farmer's market experience increased by one year, the probability of being market oriented and its intensity of market orientation for whole sampled population and market oriented only would be increased by $0.66 \%$ and 0.15 and 0.11 respectively, other things remain constant. The wheat market experience is the main basis for leading the farmers to be perfect in knowledge and skills of marketing activities so that it had positive association with market orientation.

Extension contact: The frequency of extension contact was the main determinant for wheat market orientation. It was positively related to market orientation of wheat crop production and was significant at 5\% significant level. Keeping other variables constant, as the number of extension contact increased by one, the probability of being market oriented would be increased by $7.90 \%$ while its intensity for whole sample and for those who are already market oriented would increase by 1.82 and 1.28 respectively. This is consistent with the finding of Onubuogu and Onyeneke, who found a positive relationship between extension contact and market orientation of root and tuber, due to increment of production that led to market oriented farmers [12].

Table 5. Tobit estimates and marginal effects for determinants of wheat market orientation.

\begin{tabular}{|c|c|c|c|c|c|}
\hline \multirow{2}{*}{ Variables } & \multirow{2}{*}{ Coef. } & \multirow{2}{*}{ S. E } & \multicolumn{3}{|c|}{ Marginal effect } \\
\hline & & & $\operatorname{Pr}(\mathbf{Y})$ & $\mathbf{E}(\mathbf{Y})$ & $E\left(Y^{*}\right)$ \\
\hline Age (year) & .037732 & .1086439 & .0009557 & .0155034 & .0219557 \\
\hline Sex (Male/female) & .1402487 & 3.93043 & .0035546 & .0575236 & .0814434 \\
\hline Family size (AE) & $-5.737433 * *$ & 2.435256 & -.1453277 & -2.357405 & -3.338532 \\
\hline Education (year) & .4002048 & .3292798 & .0101371 & .1644367 & .2328735 \\
\hline Land size of wheat (ha) & $23.0403^{* * *}$ & 5.342155 & .5836048 & 9.466832 & 13.40683 \\
\hline Amount of fertilizer (quintal) & 3.325598 & 2.168564 & .0842365 & 1.366427 & 1.935119 \\
\hline
\end{tabular}




\begin{tabular}{|c|c|c|c|c|c|}
\hline \multirow{2}{*}{ Variables } & \multirow{2}{*}{ Coef. } & \multirow{2}{*}{ S. E } & \multicolumn{3}{|c|}{ Marginal effect } \\
\hline & & & $\operatorname{Pr}(Y)$ & $\mathbf{E}(\mathbf{Y})$ & $E\left(Y^{*}\right)$ \\
\hline Improved Variety (yes/no) & 2.888644 & 3.452414 & .0732255 & 1.179812 & 1.668288 \\
\hline Amount of Labor (number) & 2.904152 & 2.478043 & .0735614 & 1.193262 & 1.689885 \\
\hline Total Input Cost (birr) & $-.0022503 *$ & .001304 & -.000057 & -.0009246 & -.0013094 \\
\hline Market access (yes/no) & $11.3901 * * *$ & 3.04372 & .282981 & 4.676302 & 6.556407 \\
\hline Wheat market experience (year) & $.2602628^{*}$ & .1434306 & .0065924 & .1069371 & .1514433 \\
\hline Distance to nearest market (hour) & 1.939515 & 1.414936 & .0491274 & .7969108 & 1.128577 \\
\hline Distance to all weather road (hour) & -1.365819 & 1.989555 & -.0345958 & -.5611894 & -.7947506 \\
\hline Extension contact (number) & $3.120455^{* *}$ & 1.290126 & .0790403 & 1.282137 & 1.815749 \\
\hline Credit (yes/no) & .4677738 & 2.8287 & .011847 & .1922557 & .2722771 \\
\hline Off/none-farm income (birr) & $-.0006491 * *$ & .0002557 & -.0000164 & -.0002667 & -.0003777 \\
\hline Quantity of wheat produced (quintal) & .5827417 & .4075861 & .0147607 & .2394377 & .3390892 \\
\hline Equine (TLU) & $4.668504^{*}$ & 2.741222 & .118252 & 1.918201 & 2.716537 \\
\hline Oxen (TLU) & -.6290716 & 1.675591 & -.0159342 & -.2584738 & -.3660479 \\
\hline TLU Excluding Oxen\&equine (TLU) & -.2980501 & .9395901 & -.0075495 & -.1224632 & -.1734312 \\
\hline cons & -7.50071 & 8.302358 & & & \\
\hline /sigma & 15.417 & 1.101676 & & & \\
\hline Number of observation $=190$ & \multicolumn{3}{|c|}{$\operatorname{Pr}(Y>0)=0.58$} & \multicolumn{2}{|c|}{ Log likelihood=-494.04 } \\
\hline left-censored observations $=81$ & \multicolumn{3}{|c|}{$E(Y * \mid Y>0)=7.88$} & \multicolumn{2}{|c|}{ LR chi2 $(20)=116.13$} \\
\hline uncensored observation $=109$ & \multicolumn{3}{|c|}{$E(Y \mid Y>0)=13.53$} & \multicolumn{2}{|c|}{ Prob $>$ chi $2=0.0000$ Pseudo $R 2=0.1052$} \\
\hline
\end{tabular}

Note: ***, ** and * were significant at $1 \%, 5 \%$ and $10 \%$ significant level. E $\left(\mathrm{Y}^{*}\right), \mathrm{E}(\mathrm{Y}) \& \operatorname{Pr}(\mathrm{Y})$ are conditional expectation on latent variable, observed dependent variable and uncensored observed dependent variable respectively; is MORTI.

Source: Survey result, 2018/9.

Off/none farm income: As expected, this variable had negative but significant effects on market orientation of wheat production at $5 \%$ significant level. If the farmer's off farm income increased by one birr, the probability of being market oriented farmers by wheat would be increased by $0.0016 \%$ while the intensity of market orientation would be increased by 0.00038 and 00027 for the whole sample and for those who are already market oriented respectively, other things remain constant. This means that if the farmers have more off/non-farm activities and can get more off farm income, they preferred it to wheat production and consider wheat production as a par time activities so that become non market oriented farmers.

Equine owned: In the study area, the main means of transportation for wheat producers was equine/donkey and it had a positive and significant effect on market orientation of wheat at $10 \%$ significant level. If the number of equine increased by one TLU, the probability of being market oriented under wheat, the intensity of market orientation among the whole sample and for market oriented wheat producers would be increased by $11.23 \%, 2.72$ and 1.92 respectively. This is in line with the finding of Gebremedhin and Jaleta, who found that a positive relation between ownership of equine and market orientation due to its effect of reducing marketing costs and increasing farm profitability [9].

\section{Conclusion and Recommendation}

The market orientation index of wheat in the study area was very low $(10.69 \%)$, showing that small land is allocated for wheat. The availability of larger land size with frequent extension service could enhance the wheat production so as to improve market orientation index of smallholder wheat farmers. However, small size of land was allocated for wheat production; and the extension services were provided to the farmers only twice a year. As a result, most smallholder farmers became non market oriented by wheat. Therefore, the district's agricultural office and development agents in each kebeles should provide extension by giving emphasis on best agronomic practice so as to improve the productivity of land, as a result production of wheat will be enhanced which in turn facilitates the smallholder wheat producers to be market oriented. Besides this, promoting the farmers to cultivate/produce more wheat by allocating on large size of land would be recommended. The smallholder wheat producers in the study area were less accessed to market and were not experienced in wheat market although the better market access with many years of wheat market experience could enhance the level of market orientation. Thus expansion of market nearest to their home and extending the use of technologies (to get market information) for rural farmers should be promoted by government intervention, through improving market infrastructure, marketing facilities and encouraging contract farming.

Input/production cost hinders smallholder wheat farmers from being market-oriented farmers was due to the higher cost of production. Therefore, policies that reduce the production cost, through supplying least cost (locally available) but high quality input to farmers, should be designed so as to encourage them to be market oriented farmers. Off/none farm income negatively and significantly affected market orientation of smallholder wheat farmers due to their higher tendency on it rather than wheat production so that encouraging the farmers to use their off farm income on production of wheat, through awareness creation on importance of wheat market, should be promoted. Extension contact was also among the significant factors affecting market orientation of smallholder wheat farmers. However, the development agents/extension providers provide extensions mainly with the intention of production only twice 
a year, not focused market orientation. Thus, the extension provider should provide the extension by incorporating the marketing part and increase the number of extension contact. Family size affected market orientation of smallholder wheat farmers negatively and significantly due to lack of enough production for market because of higher consumption needs. Therefore, using family member as a labour to increase the production of wheat, which enable them more market oriented and participant, would be promoted by the extension providers in the district.

This research was mainly focused on smallholders' market orientation of wheat production. So, the future research should conduct a research by giving much emphasis on the smallholder farmers' market orientation of other agricultural products in the study area.

\section{Abbreviation}

CSA: Central Statistical Agency; ECX: Ethiopian Commodity Exchange; DARDO: District's Agriculture and development Office; MORTI: Market Orientation Index

\section{Declaration Section}

\section{Ethics Approval and Consent to Participate}

Ethical approval and consent to participate is not applicable for this study.

\section{Consent for Publication}

Not applicable.

\section{Availability of Data and Materials}

The data sets used and/or analyzed during the current study are available from the corresponding author on reasonable request.

\section{Funding}

Not applicable

\section{Acknowledgements}

We would like to thank Jimma University College of Agriculture and Veterinary Medicine, International Livestock Research Institute (ILRI) for giving us a chance to use different accesses (library service, internet access etc.) needed for this work.

\section{References}

[1] Abu Tefera, 2013. Report Contains Assessments of Commodity and Trade Issues Made by USDA Staff and Not Necessarily Statements of Official U.S. Government Policy, Ethiopian Grain and Feed annual report.
[2] Agricultural transformation agency (ATA), 2014. Wheat Sector Development Strategy (Working Document 20132017).

[3] Boka GT., 2017. Climate change challenges, smallholders' commercialization, and progress out of poverty in Ethiopia. In: Shimeles A, Anyanwu JC, Faye I, Ngaruko F, Simpasa A, Salami AO, Verdier-Chouchane A, editors. Working Paper Series No. 253, African Development Bank. Abidjan (Côte d'Ivoire): African Development Bank.

[4] CSA (Central Statistical Agency of Ethiopia), 2007. Census 2007.

[5] CSA (Central Statistical Agency of Ethiopia), 2014. Agricultural Sample Survey. Report on Area and Production of Major Crops. Volume I, VII and VIII. Statistical Bulletin 578. Addis Ababa, Ethiopia.

[6] DARDO 2009. Districts Agricultural and rural development office report.

[7] Demeke, M., and Di Marcantonio F., 2013. Analysis of incentives and disincentives for wheat in Ethiopia. Technical notes series, MAFAP, FAO, and Rome.

[8] Dessie, A. B., Abate, T. M. \& Mekie, T. M, 2018. Factors affecting market outlet choice of wheat producers in North Gondar Zone, Ethiopia. Agric \& Food Secur 7 (91) doi: 10.1186/s40066-018-0241-x.

[9] Gebremedhin, B. and Jaleta, M., 2010. Commercialization of Smallholders: Is Market Participation Enough? (No. 3082016-5004).

[10] Joseph M. Awika, 2011. Major Cereal Grains Production and Use around the World.

[11] Mamo, T., Getahun, W., Tesfaye, A., Chebil, A., Solomon, T., Aw-Hassan, A., Debele, T. and Assefa, S., 2017. Analysis of wheat commercialization in Ethiopia: The case of SARD-SC wheat project innovation platform sites. African Journal of Agricultural Research, 12 (10): 841-849.

[12] Onubuogu, G. C. and Onyeneke, R. U., 2012. Market Orientation of Root and Tuber Crops Production in Imo State, Nigeria. Agricultural Science Research Journals, 2 (5): 206216.

[13] Siziba, S., Nyikahadzoi, K., Diagne, A., Fatunbi, A. O. and Adekunle, A. A., 2011. Determinants of cereal market participation by sub-Saharan Africa smallholder farmer. Journals of Agriculture \& Environmental Studies, 2 (1).

[14] Solomon A, Bekele S, Franklin S., 2010. Does technology adoption promote commercialization? Evidence from Chickpea Technologies in Ethiopia.

[15] Tefera, T., 2014. Determinants of smallholder pulse producers market orientation in Southern Ethiopia. Asian Journal of Business Management, 6 (2): 97-103.

[16] Weldeyohanis, S., Mitiku, F. and Negash, R., 2017. Value Chain Analysis of Malt Barley (Hordeumvulgarel): A Way Out for Agricultural Commercialization: the Case of Lemu Bilbilo District, Oromia Region, Ethiopia. Journal of Economics and Sustainable Development, 8 (13): 2222-2855.

[17] Yamane, Taro, 1967. Statistics, An Introductory Analysis, 2nd Ed., New York: Harper and Row. 